\title{
NIPA2 wt Allele
}

National Cancer Institute

\section{Source}

National Cancer Institute. NIPA2 wt Allele. NCI Thesaurus. Code C75739.

Human NIPA2 wild-type allele is located in the vicinity of 15q11.2 and is approximately 29 $\mathrm{kb}$ in length. This allele, which encodes non-imprinted in Prader-Willi/Ang elman syndrome region protein 2 , may be involved in prostate cancer. 